\title{
Affective Factors in Human Information Behavior: A Conceptual Analysis of Interdisciplinary Research on Information Behavior
}

\author{
Monika Krakowska \\ ORCID 0000-0002-2724-9880 \\ Institute of Information Studies, Faculty of Management and Social Communication \\ Jagiellonian University in Krakow, Poland
}

\begin{abstract}
Purpose/Thesis: The article contains theoretical and conceptual reflection and analysis of how emotions and other affective phenomena are defined and understood in contemporary research on human information behavior. The article draws attention to the interdisciplinary nature of research into affective information activities.

Approach/Methods: The reported research employs a qualitative approach, relying on critical literature review, and conceptual and thematic analysis. The analyzed material came from select publications from 2014-2020.

Results and Conclusions: Information science studies the role of emotions in information behavior. However, the application of the affective paradigm remains very limited. The affective understanding of information activities should be constantly expanded on an interdisciplinary basis with reference to theories and methods of other disciplines, such as psychology.

Originality/Value: The article studies the development of the theoretical affective phenomenon paradigm and presents the most important approaches psychology takes to emotions. By analyzing the latest trends in the study of affective information behaviors, the study joins the collaborative effort to develop an agenda providing a theoretical and practical basis for the development of interdisciplinary research within the affective paradigm.
\end{abstract}

Keywords

Affective paradigm. Emotions. Information behavior. Interdisciplinary approach. Psychology of emotions. Qualitative analysis. Qualitative content analysis.

Received: 22 June 2020. Reviewed:16 July 2020. Revised: 10 September 2020. Accepted: 21 September 2020.

\section{Introduction}

An interdisciplinary approach to research on human information behavior (HIB) requires a cohesive and holistic view of an individual whose various activities, including broadly understood information activities and processes, depend on many factors explored in various disciplines other than information science, such as psychology, sociology, philosophy, biology, cognitive science, and medicine. Following of theories and concepts between disciplines, both in social and natural sciences, information science scholars 
should consider expanding their discipline by researching and establishing a multifaceted, universal view of undertaken analysis and creating new concepts, by employing different approaches to specific issues and phenomena. This would contribute to the development of the affective paradigm that creates an entity-sensitive multidisciplinary framework forming the basis of further explorations of the subjective aspect of information behavior, as well as the implementation of multifaceted research and the use of various qualitative methods (Hartel, 2019).

This study has two main goals. First, it intends to verify and offer a synthesized picture of research in the area of human information behavior conducted within the affective paradigm through a systematic review of the distributed results of investigations characterizing particular affective factors. Secondly, the goal is also to describe the psychology of emotions in order to develop theoretical and terminological foundations, a certain scheme and a perspective for research into affective phenomena in information behavior. The article introduces a conceptual view of the study of affective factors by presenting key theories, concepts and terms of psychology of emotions. The article focuses on this, because proper understanding of affective phenomena deepens the understanding of the influence affects, feelings and emotions have on information processes undertaken by an individual user in a variety of contexts. To this end, conceptual analysis was carried out to find out how researchers approached the study of affective factors, the features and role of affect, emotions and feelings, and their impact on the information behavior. In order to expand the interdisciplinary perspective in information science research, the review also included publications concerned with information behavior studied within the affective paradigm, which indicate global trends in the research on affective factors in information processes. The most important theories of emotional psychology provided a starting point, as they allow scholars to understand the ways in which affective factors function and impact human information behavior. Undoubtedly, emotions are an integral part of any information activity, as they affect the information users' attention, memory, performance, evaluation and judgments: they found opinions and affect the users' understanding of the world (Fourie \& Julien, 2014a; Lopatovska, 2014; Nahl \& Bilal, 2007). Studies on emotions in information behavior have been conducted since the late 1980s which marked the affective turn in information and library studies (Hartel, 2019). This paper examines the state of research on affective information processes, and explores the general state of the study of more specific issues, such as, terminological chaos, affective barriers, information retrieval processes and verification of information behavior models (Lopatovska \& Arapakis, 2011; Savolainen 2015 ; 2016).

The research identifies affective factors determining multiple human information activities. Understanding what affective conditions, comprising emotions, feelings, and affects, are, is crucial for interpretation and precise and versatile exploration of human information behavior. Taking into account the multiplicity of concepts, theoretical frameworks and interpretations of information behaviors, they will be primarily understood here as activities, actions and reactions of a person related to information, both individual and collaborative (Wilson, 2013). Information behavior may include seeking, searching, acquiring, receiving, storing, collecting and using information in the contexts within which the individual operates. Furthermore, all these activities are also characterized as conscious or unconscious, dynamic, diverse and multidimensional information processes (Cisek 2017a; 
2017b; Krakowska 2016). Appropriate comprehension and scrutiny, next to a suitable conceptualization of emotions, are the foundation of a valid research process and of the further development of an interdisciplinary approach in information science. The analysis presented in the article, focusing solely on the fundamental approach to psychology of emotions, constitutes only a basic and preliminary step to expanding the affective paradigm. The study was limited by the exclusion of the issues of cognitive and social psychology from the qualitative analysis. Further, more in-depth, grounding interdisciplinary research on affective phenomena in information behavior remains to be carried out.

\section{Conceptual framework}

\subsection{Emotions in the context of psychological theories}

The intricacies of information processes and the complexity of the person themself and their functioning, their reactions to internal and external factors, and the multiplicity of concepts and paradigms employed to study these, are the reasons why there is no uniform definition of emotions (Cowie, Sussman \& Ben-Ze'ev, 2011). Generally speaking, scholars agree that an "emotion" is definitely a short-term psychological and physiological phenomenon involving cognitive processes, as well as physiological and bodily reactions. At the same time, it directs human action through registered information, prompts assessments reactions, and profiles the individual's choices (Lopatovska, 2014; Payne \& Cooper, 2001). Evidence arising from the considerations and practices of psychology and related sciences, including information science, confirms that humans are by nature an emotional being, and that emotions inform their development, actions and behavior in various ways. It should be noted that psychology's definition and understanding of emotions and affective factors may be different than those employed, e.g., in biology, focusing on mental processes, the brain functions, and bodily reactions (Damasio \& Carvalho, 2013; Fourie \& Julien, 2014a; 2014b; Gallagher, 2014), or in sociology, which prioritizes the creation of mutual social relations through emotional phenomena (Crisp \& Turner, 2015). The next part of the article focuses on the fundamental issues in the psychology of emotions, including key definitions, theories and approaches to the affective phenomena.

\subsection{Affective phenomena, affective realm}

A critical difficulty in understanding and defining emotions is the lack of scholarly consensus regarding the difference between emotions and related affective phenomena, such as feelings, moods, sentiments, and affective traits (Savolainen, 2015). Developing more precise definitions of individual concepts and phenomena should result in a comprehensive characterization of the affective realm (Ben-Ze'ev, 2000). Affective phenomena can be analyzed from two perspectives, i.e., intentionality and availability, which makes it possible to divide them into their basic types. These include (1) emotions, treated as specific conditions with intentionality, e.g. anger; (2) sentiments that are particularly conscious, but also subjective for an individual, e.g. sadness; (3) mood, which is a general intentional state, e.g. being satisfied; (4) affective features, which are also general and purposeful, but refer 
to specific predispositions of the individual, e.g. shyness (Ben-Ze'ev, 2000). Furthermore, the categorization of affective phenomena, slightly modified and expanded to include neurocognitive knowledge, identifies six most important factors of the affective domain: (1) emotions, meaning short, physiological, cognitive-behavioral episodes that optimize a person's response to significant stimuli, internal or external situations; (2) feeling, constituting a subjective and individual, more or less complex representation of emotions; (3) mood, which is less intense than emotion, and lasts longer, constituting a diffuse affective state; (4) attitude, which is a permanent phenomenon and determines human beliefs and preferences; (5) affective style, defined as a specific feature of emotional reactivity, human affective replica in the context of assessment, evaluation of phenomena, people, objects; (6) temperament, determined by genetic factors, which is a set of personality traits, i.e., internal affective, cognitive and biological conditions along with schematic reactions to the external context in which the individual functions (Davidson et al., 2003; Savolainen, 2015).

\subsection{Affect}

Affect is a complementary building unit of emotions; it is the so-called affective core consisting of two values: hedonic (associated with processing of feelings of pleasure and dissatisfaction, which affects motivation and decision-making) and arousal (rest-activated; it usually involves a physiological response and is associated with the body's stimulation) (Alcaro et al., 2017; Duncan \& Barret, 2007; Gu et al., 2019). "Affect" and "emotion" are often used interchangeably, but affect is a separate phenomenon and a fundamental step in the body's process of interaction with stimuli, the instinctive response to stimulation before conventional cognitive processes produce a more complex emotion. Biologically speaking, a reaction to stimuli can occur without perceptual and cognitive coding. Moreover, it can precede the cognitive assessment of the stimulus and the associated situation or subject (Murphy \& Zajonc, 1993). Affect refers to the mental equivalent of internal bodily representations associated with emotions, activities that require a certain degree of motivation, intensity and strength, or even personal disposition. Affects are divided into primary and secondary and have a specific value defined as an affect mark. Primary affects are attributes of emotional processes that do not involve cognitive processes and occur as a result of basic neurological mechanisms of evaluation. They regulate emotional responses developed in the process of evolution. Secondary affects, which are attributes of emotional processes, arise as a result of valuation mechanisms and conscious cognitive assessment of the environment (Barrett \& Bliss-Moreau, 2009).

\subsection{Emotions}

Emotions are variously defined as emotional states, states of automatic arousal, emotional phases that evaluate and give positive or negative meaning, and changes in the stimulation of the disposition of activity (Lopatovska \& Arapakis, 2011). Despite the lack of a uniform definition, most scholars agree that emotions are constructs based on spinal affect and behavioral response, cognitive assessment, attribution and neurophysiological changes that are a response to an affective, emotional-saturated stimulus (Russell, 2003). Emotion is understood as a biopsychosocial and impermanent reaction with an adaptative value 
(Matsumoto \& Ekman, 2009, 69). Additionally, emotions consist of components that are common to the produced prototype episodes which determine whether emotions belong to a particular psychological perspective: phenomenological, evaluative, physiological expressive, behavioral and mental. Such a diverse approach allows for the development of various perspectives correlating with the subject of specific research in many disciplines. Even scholars that share a perspective, or a conceptual framework, may have different answers to the question of what "emotion" is. It is interpreted with a reference to feelings, evaluation, and motivation. According to the "feelings paradigm", emotions are specific and conscious experiences. Within the "evaluation paradigm", emotions are defined with a reference to evaluation and judgement of the outside world: an emotion is a specific judgement, triggered in context. Within the "motivation paradigm", emotions are understood as stimulants of action (Scarantino \& de Sousa, 2018). However, it is also possible to analyze and define emotions assuming an organistic perspective (emotions as determinants of conscious emotions derived from physiological processes), or a mentalistic one (emotions as a result of mental processes; physiological and bodily responses as a consequence of mental activities). The scholars are also divided between a "classic" (biological) and a "cognitive" (Łosiak, 2007) approach. Moreover, emotions also appear in an evolutionary context, related to the search for behavioral patterns and active adaptation processes (Cosmides \& Tooby, 1997). The biological approach to early feeling defines emotions as phenomena processed in the limbic system, through specific centers in the brain, e.g. a) thalamus, the cerebral cortex (this is the basis of Cannon-Bard's thalamic theory of emotions, according to which impulses are released into the autonomic nervous system and cause emotional behavior) (McCarty, 2016) or b) amygdala, which determines the emergence of the so-called declarative emotional memory, when the brain remembers a specific emotion and reacts in a specific, remembered way to recognized stimuli (LeDoux \& Brown, 2017) or c) at the level of bodily responses (Coleman \& Snarey, 2011). According to the Schachter-Singer theory, emotions and affective reactions arise as a result of receiving information from two systems: the internal state regulated by the hypothalamus and limbic system and the external environment, or context in which the internal state occurs (Barrett \& Bliss-Moreau, 2009).

Certain scholars are developing cognitive understandings of emotions (Fox, 2018; Scherer et al., 2001), interpreting emotions as cognitive and causal, the result of perception, or of assessment. The role of cognitive processing, recognition and evaluation of the cognitive stimulus in producing emotions synchronized with many complex bodily, perceptual and cognitive processes is crucial in the causal understanding of emotion. It is therefore not possible to experience emotions without assessing a particular stimulus. Emotions are judgments, resulting from conscious or unconscious, intentional or unintentional cognitive analysis, causing an emergence of thoughts or beliefs, but also a physiological response. Emotions can therefore inhibit or motivate actions (Bechara \& Damasio, 2005; Lazarus, 1999). The signal to generate emotions is used to control the organization of the brain in order to prepare the mechanisms of action and the body's resources. This signal is also used to draw attention, establish bias in cognitive processing, and produce awareness of an affective phenomenon. Emotions simplify the decision-making process by quickly marking intentional prefrontal cortex options as positive or negative in the light of their expected emotional consequences (Damasio, 2003). The so-called network theory of emotions deserves a mention as well. It assumes that emotions are units or nodes in a semantic web, 
with numerous connections to related ideas, physiological system, muscle reaction and patterns of expression. Cognitive activity may be conscious or unconscious, intentional or unintentional; it takes the form of judgment or reflection (Bower \& Cohen, 1982). This activity is also referred to as a cognitive assessment: it verifies reactions to the external environment and determines the importance of emotional quality and individual experiences (Lazarus, 1999). Emotion can be a reaction (adequate or inadequate) to an important affective event; such a reaction then consists of affect, awareness of the emotional object and further assessment of the object, readiness for action and automatic arousal (Frijda, 2016). It is a response to a change that is important for an individual, functioning to prepare and initiate action, and motivate activity (Izard, 2007). Certain scholars analyze emotions as intermediaries between the preceding event and the implication of a particular episode (White, 2015). They understand emotions as a process, a phenomenon embedded in social and psychological phenomenon, which creates the context for their understanding, paying attention to interrelationships with mental activities and actions. Because of their social dimension, emotions may also be defined as a discourse, a tool for interpreting the social environment, reality and surroundings. Emotions have an adaptive role in social relations; they are a mental and cultural construct, separate for each individual (Barrett, 2017; Scherer \& Ekman, 2014).

\subsection{Taxonomy of emotions}

Various attempts to classify emotions were made in psychology. Four classes of emotions are distinguished: a) pre-emotions, initiating activity, based on the somatic theory of emotions (Murphy \& Zajonc, 1993) - these are indistinct, imprecise impressions, imaginations causing certain reactions; b) basic emotions, such as joy or sadness; c) primary cognitive emotions resulting from pre-emotion processing; d) secondary cognitive emotions, which are complex emotions consisting of many external or internal determinants affecting response, action, also referred to as the Izard emotion pattern, i.e. affective states which have been evolving since early childhood (Izard, 2007; Zinck \& Newen, 2008). Other classifications divide emotions into: a) basic, innate, associated with primary affect, common to all people, regardless of the community, arising before or after the recognition of the stimulus, underlying more complex emotional evaluation processes; b) complex, shaped through experience and processed cognitive processes, thoughts, mental patterns, they are derivatives of basic emotions, are dependent on conscious judgments and are social in nature (Johnson-Laird, 2007).

According to discrete emotional theory, primary emotions are biologically determined responses expressed and recognized in essentially the same way by everyone, regardless of ethnic or cultural background. Furthermore, under this theory, there are between seven and ten basic emotions and thousands of words related to emotions (Magai \& Izard, 2007), such as happiness, surprise, sadness, anger, disgust, contempt, and fear. The research on the recognition of facial expressions also distinguishes general types of emotions: fear, sadness, anger, disgust, surprise and happiness (Ekman, 1999). The circular model of emotions, proposed by Plutchik, assumes the existence of eight basic emotions, reactions to sensory stimuli, diverse in value and valence. In the model they function as diadems of opposing emotions: surprise and expectation, fear and anger, sadness and joy, disgust and liking. An important assumption in this theory is that selected emotions play a regulatory 
role, where one enables another or easily occurs together during an affective reaction and creates mixed emotions (TenHouten, 2017).

Emotions can be additionally characterized by three dimensions: pleasurable to non-pleasurable, arousing to subduing, and strained to relaxed, which are then optimized for the pleasantness - unpleasantness, attention - rejection, and level of activation perspective (An et al., 2017). Research suggests that there are both positive and negative dimensions associated with specific emotions. Emotions can also have conflicting consequences when, e.g., positive emotions lead to negative consequences of an affective reaction (Tan \& Forgas, 2010). Furthermore, there are so-called epistemic emotions, which are described as particularly important in the search for knowledge and understanding as they are related to achieving goals (Vogl et al., 2020).

\subsection{Feelings and mood}

Feelings result from actions; they provide information about human activities (Laird, 2007). They can be subjective, and independent of the impressions, thoughts or images that cause them. They are usually divided into positive, or negative, although they may have more specific intrapsychic characteristics. Feelings result from complex and conscious cognitive processes, which makes them inextricably interlinked (Burkitt, 2002). The physiological responses of the body to various situations are subjectively interpreted during cognitive processes, and then, basing on processed information, they are constructed at the cognitive level in emotions that affect the formation of feelings (Laird, 2007). Feelings further differ from emotions in that they are purely mental (Feelings, 2020). Nevertheless, they facilitate social relations with the outside world and constitute peculiar social interrelationships that allow any modification of group behavior (Burkitt, 2002).

Mood is a phenomenon analyzed incidentally in the studies of emotions or motivations (Delancey, 2006). It usually refers to a diffuse affective state, which is often less intense than emotions, but lasts longer (Ellenbogen, 2005; Russel, 2003). It is one of the basic determinants of the mental well-being of an individual and determines their mental health (Larsen, 2000). Similarly, to emotions, it depends on various external factors, the environment and context, as well as on internal physiological, cognitive and mental processes (Davidson, 2003). Just like emotions, a mood may be positive or negative (Ekkekakis, 2013). Mood can be treated as an emotional reaction and a response to the overall functioning of the body (Delancey, 2006). These are seemingly objectless affective states (Frijda, 2016). According to Ekman, a given moods seem to lower the threshold of arousing emotions that are likely to occur when a person is in that specific mood (Ekman \& Davidson, 1994). The mood is treated as subjective or empirical, a sensory component of all related affective states, including emotions. Importantly, it covers all subjective states of feelings, not just the experiences that accompany classic, prototypical emotions. Mood does not share all components with emotions: the associated peripheral physiology, facial expression, or action tendencies, are not as pronounced or distinct as in emotions (Ekkekakis, 2013). The tasks and functions characteristic of the mood include preparatory processes or warning of a specific situation, or object and consequently informing cognitive processes, as well as reducing the threshold for triggering correlating emotions (Ekman \& Davidson, 1994). 


\section{Affective paradigm in the information behavior research}

\subsection{Research scope}

As Fourie and Julien (2014a) note, researchers are often not aware of recent developments in analysis of emotions and affect in information behavior. The development of research following the affective paradigm, however, requires refinement, and an interdisciplinary view in line with the developments in psychology and sociology of emotions. A study of emotion from the perspective of information science is fundamental for the development of multidimensional research. Emotions are related to the evaluation of situations, events, objects, and people. They are also an element of cognitive processes, related to creation of knowledge. Moreover, they motivate or inhibit many reactions and conscious actions. They inform multi-context social relations. Thus understood, emotions are studied as an influence on information processes, on the creation and use of information systems, and on the use of the new forms and tools of communication and information (Lopatovska \& Arapakis, 2011). Another part of research on affective research is establishing an affective-cognitive framework for acquiring and creating knowledge, verifying models of information behavior and information activity in various contexts, or the impact of emotions on the implementation of information processes. The study of emotions in information science also concerns the impact of emotions on the realization of information processes, as well as the users' affectivity, their emotions, affective patterns, limitations, needs regarding information, awareness, dynamics of conscious cognitive and somatic actions, exploring the micro and macro emotional information environment (Fourie \& Julien, 2014a; Lopatovska, 2014; Nahl \& Bilal, 2007; Savolainen, 2015; 2016). Efforts were also made by scholars to implement the achievements of psychology and cognitive science into models of information behavior. The patterns of affective information activities are included in the information behavior models of Kulthau, Wilson, and Dervin (Wilson, 2013); affective components are also an important module of concepts of Chatman, Fisher or Sonnevald (Burnett et al., 2008; Cisek \& Krakowska, 2019; Krakowska, 2017).

\subsection{Goals}

The aim of this study, following the characterization of various parts of the affective realm, is to provide a synthesis of the latest, interdisciplinary research on the place of affective realm in information behavior. The article answers the following questions: 1 ) what affective factors related to general psychology, psychology of emotions have been recently studied in the context of human information behavior; 2) how are affective factors understood: are they analyzed as key components of information behavior, or are they identified as incidental to human information activities; 3 ) what is the current position of psychological theory in the study of information science - whose research, concepts and models the authors most often refer to in research on emotions in information behavior; 4) what methods are most often used in the study of emotions and affect in information behavior - are the methods of psychological research applied; 5) which users are most often examined in the studies of the place of affect in information behavior? 


\subsection{Methodology}

To focus on affective factors in information behavior, the research prioritized the impact, assessment, display of registered emotions, feelings, and affects in various information activities. The analysis also included review of publications that give an idea of the research undertaken in the area of human affective information behavior. The studies from the areas of cognitive psychology and social psychology were beyond the scope of this analysis, although some of their research interests, such as investigating causes and effects of emotional and mental reactions, defining affective factors, and exploring the cognitive role of emotions and the influence of the group on the individual, are present in the study insofar as they are shared by the discipline of psychology. Analyses referring to evolutionary psychology, biological and cultural conditions for understanding the external world, as well as those based on the theory of personality as a set of relatively constant traits, their psychological identity, and patterns of adaptation of an individual to the environment, taking into account the set of internal conditions, have also been excluded from the analysis. These directions remain to be explored in further interdisciplinary research of information behavior.

The article presents results of a qualitative strategy (Nowell et al., 2017) comprising of critical review of literature (Cisek, 2010), conceptual analysis (Furner, 2004) and thematic content analysis (Cisek, 2014). Earlier review publications, especially Fourie and Julien's (2014a), which summarized the most important research on affect between 2009 and 2013, became the basis for continuing the analysis and the reason for the selection of the period. While foreign research on information science has been making use of the affect theory since the 1990s (Hartel, 2019), it remains rare in Poland. Nevertheless, a growing interest in the place of affect in information behavior is evident in Polish scholarship, as it has been studied by Sobielga (1997; 2000), Kisilowska and Mierzecka (2019), Krakowska (2017), Cisek and Krakowska (2019). Thus, an additional intention of this publication is to update the knowledge on research on the place of affective phenomena in information behavior and to draw attention to the potential of interdisciplinary research in information science.

A critical review of literature was conducted to determinate the extent of affect theory's presence within the HIB field. In May 2020, the LISTA and SSCI/Web of Knowledge databases were searched with the combination of phrases "information behaviour or information behavior", "emotion", "affect”, "feeling" "mood", "emotional state", "research" with limitations to years 2014-2020 and English language. Over 320 publications were retrieved, which subject to further selection based on abstracts and keywords. After eliminating duplicates, 35 relevant publications were selected ( 34 articles and 1 dissertation). The databases of the Digital Libraries Federation, CORE, CeON Agregator, Media Library, and Google Scholar were also searched in order to verify and expand the search by the publications in Polish related to the issues of testing emotions in information behavior. After verifying the received articles, no publications that would meet the criteria were found

The analysis was limited to general psychology of emotions, eliminating issues related to cognitive psychology and social psychology. Issues related to emotions and other affective factors, both in psychology and information science are so extensive that they require a rather complementary approach and analysis in research, even at the theoretical and conceptual level. The social and cognitive dimension of affective information behavior remains to be explored in further explanatory studies. 


\section{Results}

Qualitative content analysis of selected publications on affective phenomena in information behavior showed that currently, the most frequently undertaken studies are those where emotions are a secondary result of the exploration of information behavior. The study of emotions as key components of information behavior most often concerns model verification and tends to focus on the processes of information searching and seeking. Among those publications, the reviews published by Fourie and Julien (2014a; 2014b) and O'Brien, Dickson and Askin (2017) are noteworthy. The authors recommend further research in the area, especially research of affective factors. This could mean a study of emotions in the library and information science environment, emotions in the library and information science (LIS), the study of affective information behavior. It should interest researchers who would do well to incorporate knowledge about emotions into their study of information practice and education of LIS professionals (Fourie \& Julien, 2014b). The authors make clear that there is a need for a more systematic review of cognitive and affective factors, personality variables, and their impact on information searching and information retrieval, particularly as related to the fast development of new technologies and information searching systems, as well as to the diversity of digital sources and the use of networks and social media. Fourie and Julien also recommended that scholars use more mixed methods in research evaluating physiological factors to see individual differences from new perspectives, as well as to analyze professional user groups with developed information competences (O'Brien et al., 2017). Similar conclusions regarding the need for further research on the place of affect in information behavior might be drawn from the content analysis of the select articles.

Tab. 1. Thematic categories - number of terms referring to the various categories of affective phenomena issue in the research on information behavior in the period 2014-2020

\begin{tabular}{|c|c|c|c|c|c|c|c|c|}
\hline Categories & & 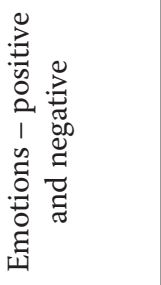 & 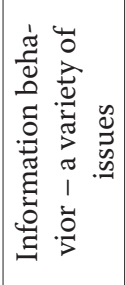 & 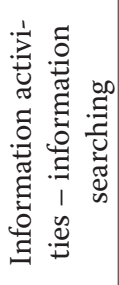 & 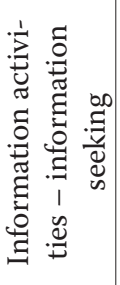 & 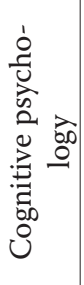 & $\underset{\mathscr{U}}{\stackrel{U}{Z}}$ & 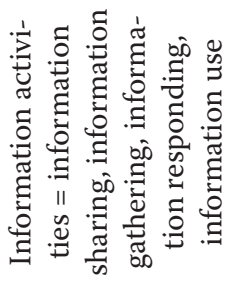 \\
\hline $\begin{array}{l}\text { Number of terms } \\
\text { related to category }\end{array}$ & & 94 & 26 & 22 & 21 & 19 & 16 & 11 \\
\hline Categories & 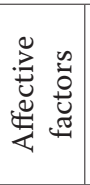 & 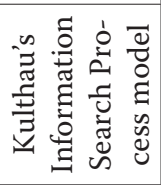 & 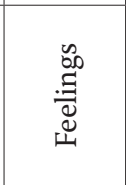 & $\begin{array}{l}\overrightarrow{0} \\
\stackrel{0}{\Sigma}\end{array}$ & 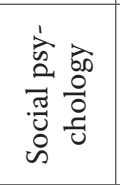 & $\underset{\mid \Xi}{\Xi}$ & 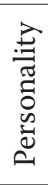 & 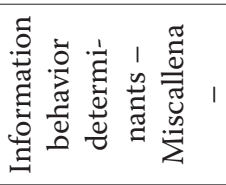 \\
\hline $\begin{array}{l}\text { Number of terms } \\
\text { related to category }\end{array}$ & 8 & 7 & 7 & 4 & 3 & 3 & 1 & 27 \\
\hline
\end{tabular}

As part of the thematic analysis, the given issue based on theoretical framework, topics, users examined, and methodology occurred in all 35 articles published in scientific journals between 2014 and 2020 were selected and then coded. Subsequently, these elements 
were categorized according to their frequency of appearance. In the Table 1 all categories assigned to affective phenomena in information behavior research are presented.

\subsection{Research on affective factors}

The study showed that affective factors, especially emotions, are analyzed in various ways. The term "emotion" is used arbitrarily to describe various affective states, without categorizing them into core affective states, emotions, feelings, or moods (94 different terms describe emotions, 16 of which concerned definitely positive, and 14 negative emotions). Eight texts mentioned general affective factors (e.g. Behesti et al., 2014; Canning \& Buchanan, 2019; Meyer \& Fourie, 2017; Zanganeh \& Hariri, 2018). However, the authors tried to be more specific when analyzing the results of the research (e.g. after selecting negative emotions, mood, feeling). The term "affect" itself appears only in four articles, and the authors understand it as an emotional state, or an aspect of it (Fitzgerald, 2018; Fourie \& Julien, 2014b; Julien \& Fourie, 2015; Meyer \& Fourie, 2017). Emotions are usually divided into primary and secondary or positive and negative. Negative emotions, such as those associated with depressive disorders, receive particular attention (Campbell et al., 2018), as do negative emotions (fear, anxiety) determining the passive information behavior of the incarcerated (Canning \& Buchanan, 2019), or the frustration of scientists in the process of information retrieval (Ashlee, 2015). The role of emotions and moods was considered in the studies of the relationship between primary and secondary emotions, and of the mood as the reaction during online information search. The possibility of creating a unified affective information search model was raised in passing in a study based on the analysis of facial micro expression to identify patterns of different emotions (Lopatovska, 2014). Furthermore, certain articles also discussed negative emotions related to depression and anxiety, and their impact on the information search process, formulating and applying emotionally charged keywords to the search. The results showed a strong influence of affective states on the user's functioning, their thought processes and problems (Campbell et al., 2018).

\subsection{Psychological theories used in research}

Only 14 publications studied behavior explicitly borrowed theoretical frameworks from the discipline of psychology. Different authors made similar use of the borrowed methods and tools (Lopatovska, 2014). Moreover, the methods applied in medicine as electrocardiography and the analysis of physiological processes at the level of the activity of internal organs in correlation with emotions through the electrical measurement of skin conductivity, were also used (Ashlee, 2015). Nevertheless, it is clear that there is much more to be done in the area of affect research within the discipline of information science. There are more methods to be used as a part of interdisciplinary cooperation, and theoretical frameworks, grounding the study of affect, to be borrowed. Along with the psychology of emotions, issues of cognitive psychology and social psychology appeared, in 19 and three publications respectively, e.g., studies of emotions as an element of cognition, an impulse in metacognition processes and the importance of affect in learning. The combination of emotional and cognitive processes as well as the influence of emotions on the processes of knowledge creation were analyzed (Koh et al., 2019; Meyer \& Fourie, 2017; Orlu, 2016). 
Research on emotions analyzes them as key determinants of actions, where they are understood as inhibitors, activators, response or motivation to undertake information processes. Kulthau's Information Search Process model was the most often studied object of such analyzes, which is why it was listed separately in the Table 1 . However, the models including Wilson's (Santana Júnior \& Lima, 2019) or Dervin's (Koh et al., 2019; Lloyd \& Olsson, 2019; Meyer \& Fourie, 2017; O'Brien et al., 2017) were also mentioned in the research as schemas of the affective realm. A particular study evaluating a model of dynamic, conscious, and non-linear information seeking was carried out among students to map emotions which occur during the implementation of information tasks according to the patterns proposed by Ellis, Kulthau, Vakkari and Foster (Orlu, 2016). An analysis of emotion as a factor in stimulating memories, experiences as determinants of mental cognitive processes, creating mental representations, functioning like a schema of the information search process in the research strategy, is also noteworthy (Fitzgerald, 2018). Moreover, processes related to cognitive activities were explored in the context of the implementation of specific tasks, where the impact of time and difficulty of the problem were the subject of analysis. The information processes and the impact of emotions, such as frustration and uncertainty, were examined among various user groups, but most often among university students (Luo \& Nahl, 2019) or high school students conducting the research project (Kim, 2015).

\subsection{Research on emotional information behavior}

As far as information behavior and key activities are concerned, emotions were studied through their intensity of occurrence and their impact on various information processes. In addition to general analysis of information behaviors (26 publications in which the term information behavior appeared), the authors focused on the significant information acquisition processes. Among them, the following were distinguished: 1) evaluating information in relation to its source in the process of information searching, and the role of sources in effective collaborative information seeking (Wu et al., 2018); 2) intensification of emotions during a research project in students of various levels proficiency in English (Kim, 2015); 3) sharing good news that is associated with positive emotions influencing information behavior (Tinto \& Ruthven, 2014); 4) the impact of positive emotions in Chinese microblog users on their practices of sharing information (Wang et al., 2017). While analyzing various information behaviors, different issues related to the place of affect in information behavior emerged. Those were included in the category of information behavior determinants - Miscallena. It comprises the issues of dynamics and complexity of information activities, the impact of multitasking on information processes and the impact of the group on information activities. Often during the study of information behavior emotions become an additional object of analysis as researchers notice the emotions affecting information activities.

\subsection{Emotion as a reaction}

Authors analyzed emotions as reactions, exploring their influence on processes related to conscious action (Lopatovska, 2014; Orlu et al., 2017; Park, 2015; Wang et al., 2017; Zanganeh \& Hariri, 2018). Emotions resulting from cognitive processes, constituting an 
emotional reaction to various sources of information have been studied in various contexts. The reactions to information and sources of culture were examined, where the medium, in this case websites and information portals, constituted a cognitive authority that elicited various reactions, often negative. The innovative study was primarily concerned with emotional response at a specific point in the reception of information, emerging through the message and its source (Mierzecka et al., 2019). The analyzed studies also discussed the affective context of the information retrieval process and the possibility of using the knowledge of determinants that arouse emotions. The influence of affective factors on information behavior in creative work environments, such as libraries, defined as places of knowledge creation (Meyer \& Fourie, 2017) was also studied. Moreover, the authors explored determinants of information activities, such as chronic pressure, time (Liu et al., 2019), language (Kim, 2015), or the competences and the role of librarians, in identifying attributes in affective information behavior of students (determining the success or failure in performing a search task) in relation to emotions and affective reactions. Other subjects of study included attributive style of emotions and satisfaction level in the information retrieval process, as well as methods of assigning emotions to different factors and situations (Behzadi \& Sanatjoo, 2019). Ekman's achievements in cognitive and social psychology were the basis for the evaluation of emotional aspect of facial expressions. It allowed the analysis of the appearance of primary emotions through facial muscle movements, and of the impact these basic emotions have on secondary affective changes, including mood (Lopatovska, 2014). Facial expressions were also explored in studies focused on information retrieval from the web to examine the relationality of satisfying effectiveness of the information process and positive emotions of users (Zanganeh \& Hariri, 2018). Additionally, emotional mimic reactions while responding to information were explored (Mierzecka et al., 2019).

\subsection{Methodology used in research on affective information behavior}

All publications were studied based on critical analysis of literature. However, as mentioned above, only 14 articles referred to existing psychological concepts, such as Ekman's, Lazarus, or Plutchik's theories (Luo \& Nahl, 2019). Additionally, authors employed the tools used in psychological experiments, such as the PANAS - Positive Affect Negative Affect Scale (Lopatovska, 2014), cognitive stimulation, electrocardiographic analysis and the BioPac program measuring electrodermal activity (Ashlee, 2015), ROST software for emotion analysis (Wu et al., 2018) or FaceReader for the assessment of micro expression (Mierzecka et al., 2019). The term qualitative research appeared three times, quantitative - four times. The most commonly used research methods included coding and thematic analysis: it appeared in 18 articles, some of which even mentioned cover coding of selected emotions. The commonly-used tools included a) various questionnaires, including those borrowed from psychological sciences, such as the ASQ attribution style questionnaire or the satisfaction questionnaire (Behsadi \& Sanatjoo, 2019); b) recruitment interviews (16 publications in total); c) experimental methods, such as a laboratory experiment arranged in specific conditions (Ashlee, 2015; Huang \& Bilal, 2019); d) observations (six publications); e) think-aloud protocols (four publications). The memory stimulation was used once (Fitzgerald, 2018). Case study, discussion, mapping 
and research project appeared three times (e.g. Cole at al., 2015). Methods of searching diaries, focus groups, verbalization, triangulation and interview during recruitment and selection of users for research appeared twice. The number of occurrences of individual methods is presented in Table 2.

Tab. 2. Thematic categories - number of terms related to a given methodology used in the study of affective factors in information behavior for the period 2014-2020

\begin{tabular}{|c|c|c|c|c|c|c|c|}
\hline Categories & 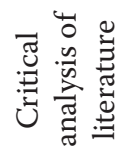 & 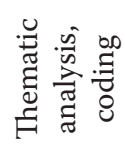 & 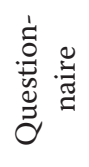 & 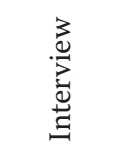 & 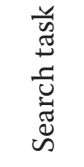 & 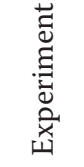 & 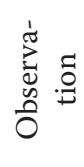 \\
\hline $\begin{array}{l}\text { Number of terms } \\
\text { related to category }\end{array}$ & 35 & 18 & 18 & 14 & 10 & 7 & 6 \\
\hline Categories & 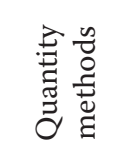 & 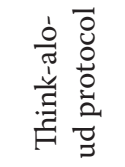 & 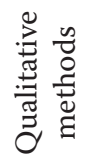 & 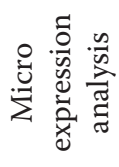 & 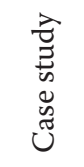 & 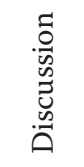 & 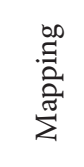 \\
\hline $\begin{array}{l}\text { Number of terms } \\
\text { related to category }\end{array}$ & 4 & 4 & 3 & 3 & 3 & 3 & 3 \\
\hline Categories & 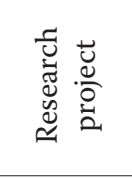 & 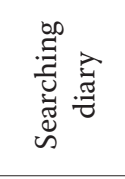 & 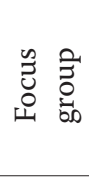 & 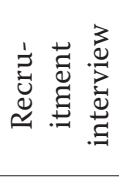 & 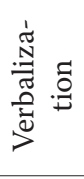 &  & 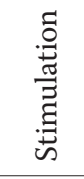 \\
\hline $\begin{array}{l}\text { Number of terms } \\
\text { related to category }\end{array}$ & 3 & 2 & 2 & 2 & 2 & 2 & 1 \\
\hline
\end{tabular}

\subsection{Users}

The study distinguished between the different categories of researched users, the types of participants selected for various studies aiming to capture specific affective components of various information activities. Among the most represented users were students, studying both information and library studies, as well as social and psychological sciences, culture management, economy and art studies (21 publications). Other groups included the Internet or Web 2.0 users as fandom participants, music band fans, YouTube users (Pennington, 2016), microblogging users. Occasionally, some peculiar users such as prisoners or car mechanics featured. The participants also included high school students (four publications), scientists and doctoral students (two publications each), and youth (two publications concerning young users suffering from depression, or generally young people aged 14-16). A rank list of types of users who were examined for affective phenomena along with their categories is presented in Table 3. 
Tab. 3. Thematic categories - number of terms referring to specific groups of users in the study of affective factors in information behavior for the period 2014-2020

\begin{tabular}{|c|c|c|c|c|c|c|}
\hline Categories & 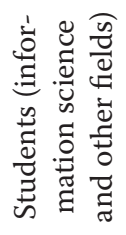 & 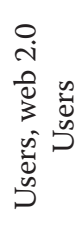 & 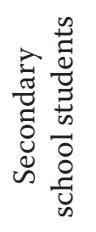 & 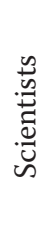 & 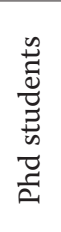 & 吾 \\
\hline $\begin{array}{l}\text { Number of terms } \\
\text { related to category }\end{array}$ & 21 & 8 & 4 & 2 & 2 & 2 \\
\hline
\end{tabular}

\section{Conclusions and limitations}

Various studies of affective phenomena indicate that emotions are an important aspect of all information activities and should be taken into account in the study of information behavior (Behzadi \& Sanatjoo, 2019; Lopatovska \& Arapakis, 2011; Savolainen, 2014). Emotions are one of the most important components of human activity, not only at the biological level, but also as a part of various processes that shape behaviors on a social, cognitive and psychological plane. Thus, they absolutely influence information activities. Because the treatment of emotions in information science has so far been limited, there is a need to extend the research to consolidate an affective perspective in this discipline. The affective paradigm is a constantly evolving, interdisciplinary set of theoretical and methodological foundations. This requires up-to-date knowledge of global developments in the area, and the adjustment of various approaches based on concepts in the field of psychology, cognitive science and sociology. This article provided an overview of terms related to affective realm, key theories and concepts related to emotions from the discipline of psychology. It also offered a synthesis of the latest exemplary international research on affective information behavior. The obtained results made clear that there is a need to constantly deepen the research on the role of emotions and other affective factors in information behaviors, which, apart from the most frequently analyzed processes of seeking, also include collecting, sharing, using, and avoiding or destroying information (Cisek, 2017). Too rarely specific theories of emotional psychology were referred to, with affective factors featuring only as a side-note to research on information behavior. Too often, different concepts such as affect and emotion were mixed up, indistinct from feelings or moods. Interdisciplinary cross-referencing from adjacent disciplines researching emotions was scarce (Lopatovska \& Arapakis, 2011). There is a need of change: information science scholars should refer to existing concepts, research, tools and methods of psychology. They also need to intensify research on the psychology of emotions by verifying lesser-known models of information behavior, going beyond the well-established tradition of examining Kulthau's model. It would be good to study more varied groups of users to explore the differences in perceived emotions, different interpretations of their functions, roles and tasks in heterogeneous and dynamic information behaviors. Finally, this article aimed to create a specific compendium of basic knowledge about affective factors. It developed an outline of selected affective information behavior research, which hopefully will contribute to the deepening 
of specialization and interdisciplinarity of information science as it draws attention to the existing gaps in the scholarship and to the potential of affect theory as a lens to be used. The author is fully aware that the selected concepts, issues, selected research areas, do not cover all dilemmas, theories and psychological approaches, including social psychology, or evolutionary psychology. Each of these issues, and its relation to information science and human information behavior, requires a separate discussion.

\section{References}

Alcaro, A., Carta, S., Panksepp, J. (2017). The Affective Core of the Self: A Neuro-Archetypical Perspective on the Foundations of Human (and Animal) Subjectivity. Frontiers in Psychology, 01 September, https://dx.doi.org/10.3389/fpsyg.2017.01424

An, S., Ji, L. J., Marks, M., Zhang, Z. (2017). Two Sides of Emotion: Exploring Positivity and Negativity in Six Basic Emotions across Cultures. Frontiers in Psychology [online], April, [06.09.2020], https://doi.org/10.3389/fpsyg.2017.00610

Barrett, L., F. (2017) The Theory of Constructed Emotion: An Active Inference Account of Interoception and Categorization. Social Cognitive and Affective Neuroscience, 12(1), 1-23, https:// doi:10.1093/scan/nsw154

Barrett, L. F., Bliss-Moreau, E. (2009). Affect as a Psychological Primitive. Advances in Experimental Social Psychology, 41, 167-218, https://doi.org/10.1016/S0065-2601(08)00404-8

Bechara, A., Damasio, A. R. (2005). The Somatic Marker Hypothesis: A Neural Theory of Economic Decision. Games and Economic Behavior, 52(2), 336-372, https://doi.org/10.1016/j.geb.2004.06.010

Behzadi, H., Sanatjoo, A. (2019). Attributional Style of Emotions and Its Relationship With Users' Search Behaviour. Journal of Information Science, 45(1), 105-116, https://doi.org/10.1177/ 0165551518782400

Ben-Ze'ev, A. (2000). The Subtlety of Emotions. Cambridge, Mass.; London: The MIT Press.

Bower, G. H., Cohen, P. R. (1982). Emotional Influences in Memory and Thinking: Data and Theory. In: M.S. Clark \& S.T. Fiske (eds.). Affect and Cognition (291-331). Hillsdale, N.J.: Erlbaum.

Burkitt, I. (2002). Complex Emotions: Relations, Feelings and Images in Emotional Experience. The Sociological Review, 50(2_suppl), 151-167, https://doi.org/10.1111/j.1467-954X.2002.tb03596.x

Burnett, G., Jaeger, P. T., Thompson, K. M. (2008). Normative Behavior and Information: The Social Aspects of Information Access. Library \& Information Science Research, 30(1), 56-66, https://doi. org/10.1016/j.lisr.2007.07.003

Campbell, A. J., F. Ridout, B. F., Linden, M., Collyer, B., Dalgleish, J. (2018). A Preliminary Understanding of Search Words Used by Children, Teenagers and Young Adults in Seeking Information about Depression and Anxiety Online. Journal of Technology in Human Services, 36(4), 208-221, https://doi.org/10.1080/15228835.2018.1518186

Canning, C. and Buchanan, S. (2019). The Information Behaviours of Maximum Security Prisoners: Insights Into Self-Protective Behaviours and Unmet Needs. Journal of Documentation, 75(2), 417-434, https://doi.org/10.1108/JD-06-2018-0085

Cisek S. (2010). Metoda analizy i krytyki piśmiennictwa w nauce o informacji i bibliotekoznawstwie w XXI wieku. Przeglad Biblioteczny, 78(3), 273-284.

Cisek S. (2017). Zachowania informacyjne. In: A. Żbikowska-Migoń \& M. Skalska-Zlat (eds). Encyklopedia ksiażki. T. 2 (643-647). Wrocław: Wydaw. Uniwersytetu Wrocławskiego.

Cisek, S. (2014). Analiza danych jakościowych we współczesnej informatologii. W: B. Sosińska-Kalata (ed.) Nauka o informacji w okresie zmian (79-88). Warszawa: Wydaw. SBP.

Cisek, S., Krakowska, M. (2019). Qualitative Analysis of Visual Data in Information Behavior Research. Zagadnienia Informacji Naukowej - Studia Informacyjne, 57(1), 7-25, https://doi.org/10.36702/zin.492 
Cole, Ch. Beheshti, J., Abuhimed, D., Lamoureux, I. (2015). The End Game in Kuhlthau's ISP Model: Knowledge Construction for Grade 8 Students Researching an Inquiry-Based History Project. Journal of the Association for Information Science and Technology, 66(11), 2249-2266, https:// doi.org/10.1002/asi.23300

Coleman A.E., Snarey J. (2011) James-Lange Theory of Emotion. In: S. Goldstein \& J.A. Naglieri (eds). Encyclopedia of Child Behavior and Development (844-846). Boston, MA: Springer, https://doi. org/10.1007/978-0-387-79061-9_3146

Cosmides, L., Tooby, J. (1997). Evolutionary Psychology: A Primer [online], [06.09.2020]. https:// www.cep.ucsb.edu/primer.html

Cowie, R., Sussman, N., Ben-Ze'ev, A. (2011). Emotion: Concepts and Definitions. In: P. Petta, C. Pelachaud \& R. Cowie (eds). Emotion-oriented Systems (8-31). Berlin: The Humaine Handbook, Springer.

Crisp, R. J., Turner R. N. (2015). Psychologia społeczna. Warszawa: Wydaw. Naukowe PWN.

Damasio A., Carvalho, G.B. (2013) The Nature of Feelings: Evolutionary and Neurobiological Origins. Nature Reviews: Neuroscience, 14(2), 143-152, https://doi.org/10.1038/nrn3403

Damasio, A.R. (2003) Looking for Spinoza: Joy, Sorrow, and the Feeling Brain. New York: Harcourt Brace \& Co.

Davidson, R. J. (2003). Seven Sins in the Study of Emotion: Correctives From Affective Neuroscience. Brain and Cognition, 52(1), 129-132, https://doi.org/10.1016/S0278-2626(03)00015-0

Davidson, R.J., Scherer, K.R., Goldsmith, H.H. (2003). Introduction. In: R. J. Davidson, K. R. Scherer \& H. H. Goldsmith (eds). Series in Affective Science. Handbook of Affective Sciences (3-7). New York: Oxford University Press.

DeLancey, C. (2006). Basic Moods. Philosophical Psychology, 19(4), 527-538, https://doi. org/10.1080/09515080600806567

Duncan, S., Barrett, L. F. (2007). Affect Is a Form of Cognition: A Neurobiological Analysis. Cognition E Emotion, 21(6), 1184-1211, https://doi.org/10.1080/02699930701437931

Edwards, A. (2015). Engaged or Frustrated?: Disambiguating Engagement and Frustration in Search. A dissertation submitted to the faculty of the University of North Carolina at Chapel Hill in partial fulfilment of the requirements for the degree of Doctor of Philosophy in the School of Information and Library Science. Chapel Hill. [online], [06.09.2020], https://static1.squarespace.com/static/56bccb403c44d80c6246148d/t/5712ec3145bf21968b6d9c2d/1460857909249/Edwards-Dissertation.pdf

Ekkekakis, P. (2013). The Measurement of Affect, Mood, and Emotion: A Guide for Health-Behavioral Research. Cambridge, UK: Cambridge University Press.

Ekman, P. (1999). Basic Emotions. In: T. Dalgleish \& M. J. Power (eds). Handbook of cognition and emotion (45-60). New York: Wiley, https://doi.org/10.1002/0470013494.ch3

Ekman, P., Davidson, R. J., eds (1994). Series in Affective Science. the Nature of Emotion: Fundamental Questions. New York: Oxford University Press.

Ellenbogen, M. A. (2005). Stress, Psychopathology, and the Regulation of Mood and Cortisol Levels. In: A. V. Clark (ed.) Causes, Role and Influence of Mood States (1-32). New York: Nova Biomedical Books.

Feeling. (2020). APA Dictionary of Psychology [online], [06.09.2020], https://dictionary.apa.org/feeling

Fitzgerald, S. (2018). The Role of Affect in the Information Seeking of Productive Scholars. The Journal of Academic Librarianship, 44(2), 263-268, https://doi.org/10.1016/j.acalib.2018.01.001

Fourie, I., Julien H. (2014a). Ending the dance: a research agenda for affect and emotion in studies of information behaviour. In: Proceedings of ISIC, the Information Behaviour Conference, Leeds, 2-5 September, 2014: Part 1, (paper isic09) [online]. Information Research. [06.09.2020], http:// InformationR.net/ir/19-4/isic/isic09.html

Fourie, I., Julien, H. (2014b). IRS, Information Services and Lis Research - a Reminder About Affect and the Affective Paradigm ... and a Question. Library Hi Tech, 32(1), 190-201, https://doi. org/10.1108/LHT-10-2013-0144 
Fox, E. (2018). Perspectives From Affective Science on Understanding the Nature of Emotion. Brain and Neuroscience Advances, 2, https://doi.org/10.1177/2398212818812628

Frijda, N. H. (2016). The Evolutionary Emergence of What We Call "Emotions". Cognition and Emotion, 30(4), 609-620, https://doi.org/10.1080/02699931.2016.1145106

Furner J. (2004). Conceptual Analysis: A Method for Understanding Information as Evidence, and Evidence as Information. Archival Science, 4(3-4), 233-265, https://doi.org/10.1007/s10502-005-2594-8

Gallagher, S. (2014). Phenomenology and Embodied Cognition. In: L. Shapiro (ed.). The Routledge Handbook of Embodied Cognition (9-18). New York: Routledge.

Gu, S., Wang, F., Cao, C., Wu, E., Tang, Y.-Y., Huang, J. H. (2019). An Integrative Way for Studying Neural Basis of Basic Emotions With fMRI. Frontiers in Neuroscience, June, https://doi.org/10.3389/ fnins.2019.00628

Hartel, J. (2019). Turn, Turn, Turn. In: Proceedings of CoLIS, the Tenth International Conference on Conceptions of Library and Information Science, Ljubljana, Slovenia, June 16-19, 2019 [online]. Information Research, 24(4), paper colis1901, [06.09.2020], http://InformationR.net/ir/24-4/colis/colis1901.html

Izard, C.E. (2007) Basic Emotions, Natural Kinds, Emotion Schemas, and a New Paradigm. Perspectives on Psychological Science, 2(3), 260-280, https://doi.org/10.1111/j.1745-6916.2007.00044.x

Johnson-Laird, J. D. (2007). Feelings. The Perception of Self. New York: Oxford University Press.

Julien, H., Fourie, I. (2015). Reflections of Affect in Studies of Information Behavior in HIV/Aids Contexts: An Exploratory Quantitative Content Analysis. Library and Information Science Research, 37(1), 3-9, https://doi.org/10.1016/j.lisr.2014.09.001

Kim, S.U. (2015). Investigating How English Language Learners Feel During their Research Project with the Framework of Kuhlthau's ISP. School Libraries Worldwide, 21(2), 85-102.

Kisilowska, M., Mierzecka, A. (2019). Emotions, Experience, Identity - Motivations of the Teens' Information Behaviour in the Area of Culture. In: Proceedings of ISIC, The Information Behaviour Conference, Krakow, Poland, 9-11 October: Part 2 [online]. Information Research, 24(1), paper isic1826. [06.09.2020], http://InformationR.net/ir/24-1/isic2018/isic1826.html

Koh, K., Snead, J. T., Lu, K. (2019). The Processes of Maker Learning and Information Behavior in a Technology Rich High School Class. Journal of the Association for Information Science and Technology, 70(12), 1395-1412, https://doi.org/10.1002/asi.24197

Krakowska M. (2016). Zachowania informacyjne człowieka. In: W. Babik (ed.). Nauka o informacji (429-455). Warszawa: Wydaw. SBP.

Lazarus R. S. (1999). Stress and Emotion: A New Synthesis. New York: Springer.

LeDoux, J. E., Brown, R. (2017). A Higher-Order Theory of Emotional Consciousness. Proceedings of the National Academy of Sciences, 114(10), E2016-E2025, https://doi.org/10.1073/pnas.1619316114

Liu, Ch., Liu, Y. H., Gedeon, T., Zhao, Y., Wei, Y., Yang, F. (2019). The Effects of Perceived Chronic Pressure and Time Constraint on Information Search Behaviors and Experience. Information Processing \& Management, 56(5), 1667-1679, https://doi.org/10.1016/j.ipm.2019.04.004

Lloyd, A., Olsson, M. (2019). Untangling the Knot: The Information Practices of Enthusiast Car Restorers. Journal of the Association for Information Science and Technology, 70(12), 1311-1323, https://doi.org/10.1002/asi.24284

Lopatovska, I. (2014). Toward a Model of Emotions and Mood in the Online Information Search Process. Journal of the Association for Information Science and Technology, 65(9), 1775-1793, https://doi.org/10.1002/asi.23078

Lopatovska, I., Arapakis, I. (2011). Theories, Methods and Current Research on Emotions in Library and Information Science, Information Retrieval and Human-Computer Interaction. Information Processing \& Management, 47(4), 575-592, https://doi.org/10.1016/j.ipm.2010.09.001

Luo, M. M., Nahl, D. (2019). Let's Google: Uncertainty and Bilingual Search. Journal of the Association for Information Science and Technology, 70(9), 1014-1025. https://doi.org/10.1002/asi.24174

Łosiak, W. (2007). Psychologia emocji. Warszawa: Wydaw. Akademickie i Profesjonalne. 
Magai, C. (2001). Adulthood: Emotional Development. In: N. J. Smelser \& P. B. Baltes (eds.). International Encyclopedia of the Social and Behavioral Sciences (156-159). Amsterdam: Elsevier.

Matsumoto, D., Ekman, P. (2009). Basic Emotions. In: D. Sander \& K.R. Scherer (eds.). The Oxford companion to emotion and the affective sciences (69-73). Oxford: Oxford University Press.

McCarty, R. (2016). The Fight-or-Flight Response. Stress: Concepts. Cognition, Emotion, and Behavior. In: G. Fink (ed.). Handbook of Stress. Volume 1, Stress: Concepts, Cognition, Emotion, and Behavior (33-37). San Diego: Elsevier.

Meyer, A., Fourie, I. (2017). Thematic Analysis of the Value of Kuhlthau's Work for the Investigation of Information Behaviour in Creative Workspaces in Academic Libraries. In: Proceedings of ISIC, the Information Behaviour Conference, Zadar, Croatia, 20-23 September, 2016: Part 2 [online]. Information Research, 22(1), paper isic1626. [06.09.2020], http://InformationR.net/ir/22-1/isic/ isic1626.html

Mierzecka, A., Wasilewski, J., Kisilowska, M. (2019). Cognitive Authority, Emotions and Information Quality Evaluations. In: Proceedings of CoLIS, the Tenth International Conference on Conceptions of Library and Information Science, Ljubljana, Slovenia, June 16-19, 2019 [online]. Information Research, 24(4), paper colis1910, [06.09.2020], http://InformationR.net/ir/24-4/colis/colis1910.html

Murphy, Sh. T., Zajonc, R. B. (1993). Affect, Cognition, and Awareness: Affective Priming With Optimal and Suboptimal Stimulus Exposures. Journal of Personality and Social Psychology, 64 (5), 723-739.

Nahl, D., Bilal, D., eds (2007). Information and Emotion. The Emergent Affective Paradigm in Information Behavior Research and Theory. Medford, NJ: Information Today Inc.

Nowell, L.S., Norris, J.M., White, D.E., Moules, N.J. (2017). Thematic analysis: striving to meet the trustworthiness criteria. International Journal of Qualitative Methods, 16, 1-13.

O'Brien, H. L., Dickinson, R. Askin, N. (2017). A Scoping Review of Individual Differences in Information Seeking Behavior and Retrieval Research Between 2000 and 2015. Library \& Information Science Research, 39(3), 244-254, https://doi.org/10.1016/j.lisr.2017.07.007

Orlu, A. D. (2016). Information Seeking Behaviour of Masters Students: Affective and Behavioural Dimensions[online]. Library Philosophy and Practice, Summer, 1387. [06.09.2020], http://digitalcommons.unl.edu/libphilprac/1387

Orlu, A. D., Mafo, I. H., Tochukwu, N.,T. (2017). Perceived Emotions in the Information Seeking Behaviour of Manchester Metropolitan University Students [online]. Library Philosophy and Practice Spring, 1534. [06.09.2020], http://digitalcommons.unl.edu/libphilprac/1534

Park, M. (2015). Human Multiple Information Task Behavior on the Web. Aslib Journal of Information Management, 67(2), 118-135, https://doi.org/10.1108/AJIM-12-2013-0154

Payne R. L., Cooper, C. L (2001). Emotions at Work-Theory, Research and Applications for Management. Chichester: Wiley-Interscience.

Pennington, Rasmussen D. (2016). The Most Passionate Cover I've Seen: Emotional Information in Fan-Created u2 Music Videos. Journal of Documentation, 72(3), 569-590, https://doi.org/10.1108/ JD-07-2015-0086

Plutchik, R. (2001). The Nature of Emotions. American Scientist, 89, 34-350.

Russell J. (2003). Core Affect and the Psychological Construction of Emotion. Psychological Review, 110(1), 145-172, https://doi.org/10.1037/0033-295X.110.1.145

Santana Junior, C.A., Lima, S. R. (2019). Information Behaviour in Facebook Focused on Brazilian Popular Music (BPM). Investigación Bibliotecológica, 33(80), 13-30. https://doi.org/10.22201/ iibi.24488321xe.2019.80.57931

Savolainen, R. (2014). Emotions as Motivators for Information Seeking: A Conceptual Analysis. Library E Information Science Research, 36(1), 59-65, https://doi.org/10.1016/j.lisr.2013.10.004

Savolainen, R. (2015). Cognitive Barriers to Information Seeking: A Conceptual Analysis. Journal of Information Science, 41(5), 613-623, https://doi.org/10.1177/0165551515587850 
Savolainen, R. (2016). Approaching the Affective Barriers to Information Seeking: The Viewpoint of Appraisal Theory. In: Proceedings of ISIC, the Information Behaviour Conference, Zadar, Croatia, 20-23 September, 2016: Part 1 [online]. Information Research, 21(4), paper isic1603. [06.09.2020], http://InformationR.net/ir/21-4/isic/isic1603.html

Savolainen, R. (2017). Information Need as Trigger and Driver of Information Seeking: A Conceptual Analysis. Aslib Journal of Information Management, 69(1), 2-21, https://doi.org/10.1108/ AJIM-08-2016-0139

Scarantino, A., de Sousa, R. (2018). Emotion [online]. In: E. N. Zalta (ed.). The Stanford Encyclopedia of Philosophy, [06.09.2020], https://plato.stanford.edu/entries/emotion/\#EarlFeelTradEmotFeel

Scherer, K. R., Ekman, P., eds (2014). Approaches to Emotion. New York, London: Taylor Francis Psychology Press.

Scherer, K. R., Schorr, A., Johnstone, T., eds (2001). Series in Affective Science. Appraisal Processes in Emotion: Theory, Methods, Research. New York: Oxford University Press.

Sobielga J.(1997). Psychologiczne aspekty barier informacyjnych - badania wśród studentów. Praktyka i Teoria Informacji Naukowej i Technicznej, 4, 13-18.

Sobielga, J. (2000). Czynniki kształtujące opinie studentów o bibliotece [online]. Biuletyn EBIB, 4(12), [06.09.2020], http://www.ebib.pl/2001/12/sobielga.php

Tan, H. B., Forgas, J. P. (2010). When Happiness Makes Us Selfish, but Sadness Makes Us Fair: Affective Influences on Interpersonal Strategies in the Dictator Game. Journal of Experimental Social Psychology, 46(3), 571-576, https://doi.org/10.1016/j.jesp.2010.01.007

TenHouten, W. D. (2017). From Primary Emotions to the Spectrum of Affect: An Evolutionary Neurosociology of Emotions. In: A. Ibáñez, L. Sedeño \& A. M. García (eds.). Neuroscience and Social Science: The Missing Link (141-168). Switzerland: Springer International Publishing.

Vogl, E., Pekrun, R., Murayama, K., Loderer, K. (2020). Surprised-Curious-Confused: Epistemic Emotions and Knowledge Exploration. Emotion, 20(4), 625-641, https://doi.org/10.1037/emo0000578

Wang, Ch. Zhoub, Z. Jinc, X. L., Fangd, Y. Leed, M.K.O. (2017). The Influence of Affective Cues on Positive Emotion in Predicting Instant Information Sharing on Microblogs: Gender as a Moderator. Information Processing E Management, 53(3), 721-734, https://doi.org/10.1016/j.ipm.2017.02.003

White, P. R. R. (2015). Appraisal Theory. In: K. Tracy, C. Ilie \& T. Sandel (eds.). The International Encyclopedia of Language and Social Interaction (1-8). Wiley-Blackwell, New Jersey, https://doi. org/10.1002/9781118611463.wbielsi041

Wilson, T. (ed.) (2013). Theory in Information Behaviour Research. Sheffield, UK: Eiconics Ltd.

Wu, D., Liang, S., Dong, J., Qiu, J. (2018). Impact of Task Types on Collaborative Information Seeking Behavior. Libri, 68(3), 231-245, https://doi.org/10.1515/libri-2017-0051

Zanganeh, Y. M., Hariri, N. (2018). The Role of Emotional Aspects in the Information Retrieval From the Web. Online Information Review, 42(4), 520-534, https://doi.org/10.1108/OIR-04-2016-0121

Zinck, A., Newen, A. (2008). Classifying Emotion: A Developmental Account. Synthese, 161, 1-25, https://doi.org/10.1007/s11229-006-9149-2 


\title{
Czynniki afektywne w zachowaniach informacyjnych człowieka: analiza koncepcyjna interdyscyplinarnych badań zachowań informacyjnych
}

\begin{abstract}
Abstrakt
Cel/Teza: Artykuł zawiera refleksję teoretyczną i koncepcyjną oraz analizę definiowania i rozumienia emocji i innych zjawisk afektywnych oraz eksplorowania afektywnych czynników we współczesnych badaniach zachowań informacyjnych ludzi. Podjęto próby zwrócenia uwagi na interdyscyplinarny charakter badań nad afektywnymi aktywnościami informacyjnymi.

Koncepcja/Metody badań: W dociekaniach zastosowano podejście jakościowe oraz metody/techniki: krytyczny przegląd literatury, analizę konceptualną i analizę tematyczną. Jakościowa analiza treści dotyczyła wybranych, reprezentatywnych publikacji z lat 2014-2020.

Wyniki i wnioski: Badania nad emocjami w zachowaniach informacyjnych, dotyczące różnych aspektów, są rozwijane w nauce o informacji. Jednak badania nadal dotyczą ograniczonego pola poszukiwawczego. Afektywny paradygmat działań informacyjnych powinien być stale poszerzany w ujęciu interdyscyplinarnym poprzez odwoływanie się do teorii i metod m.in. psychologii.

Oryginalność/Wartość poznawcza: Artykuł dotyczy próby rozwinięcia teoretycznego zjawiska afektywnego i przedstawia najważniejsze podejścia rozumienia emocji w psychologii. Analizując najnowsze trendy w badaniu afektywnych zachowań informacyjnych, wpisuje się w nowatorskie próby opracowania agendy stanowiącej teoretyczną i praktyczną podstawę rozwoju interdyscyplinarnych badań w paradygmacie afektywnym.
\end{abstract}

\section{Słowa kluczowe}

Analiza jakościowa. Emocje. Jakościowa analiza zawartości. Paradygmat afektywny. Podejście interdyscyplinarne. Psychologia emocji. Zachowania informacyjne.

MONIKA KRAKOWSKA, PhD, is Associate Professor in the Institute of Information Studies, Faculty of Management and Social Communication, Jagiellonian University in Krakow, Poland. Her research interests include human information behavior, social and affective aspects of human information activities, qualitative information behavior research, and information culture. Selected publications: The diary method and analysis of student's mental representations of information spaces as the research approach in information behavior research (2019, co-author: S. Cisek); Qualitative analysis of visual data in information behavior research (2019, co-author: S. Cisek); Efektywność indywidualnego zarządzania informacją z perspektywy zachowań informacyjnych człowieka. In: W. Babik (ed.). Zarządzanie informacją (2019); Diagnozowanie rozwiązań w zakresie zarządzania informacją w organizacji z perspektywy teorii information grounds i zachowań normatywnych. In: R. Sapa (ed.) Diagnostyka w zarządzaniu informacją: perspektywa informatologiczna (2017).

Contact to the Author: monika.krakowska@uj.edu.pl Institute of Information Studies, Faculty of Management and Social Communication, Jagiellonian University in Krakow, ul. prof. Stanistawa Łojasiewicza 4, 30-348 Kraków, Poland 